\title{
Globalizing Sociology: an Introduction
}

\author{
Srila Roy $^{1}$ • Alf Gunvald Nilsen ${ }^{2,3}$
}

Published online: 11 June 2016

(C) The Author(s) 2016. This article is published with open access at Springerlink.com

Much of the work that has gone into the making of this special issue has taken place in the context of South Africa, where the nation's universities have been sites of turmoil and protest for more than a year now. The origins of the protests that culminated in the FeesMustFall movement that swept across many of the country's campuses can be traced to a campaign that erupted at the University of Cape Town (UCT) in March 2015. Led by a coalition of staff and students, the campaign sets out to challenge what it referred to as 'the reality of institutional racism at the University of Cape Town' (http://rhodesmustfall.co.za/). The most immediate symbolic demand made by the campaign was for the statue of Cecil John Rhodes that had adorned the university grounds since 1934 to be removed - hence the campaign's name, RhodesMustFall (RMF). The demand was inaugurated by a visceral act of protest, as student leader Chumani Maxwele threw human faeces at the statue. The immediate response from UCT was to have Maxwele arrested, but university management was soon compelled to enter into negotiations with a rapidly growing movement. Negotiations were followed by a student occupation of a central administrative building at UCT - renamed by the activists as Azania House to create a space for 'free alternative versions of blackness otherwise denied by UCT' (Sebambo 2015: 2) - and by the end of the month, the UCT senate voted in favour of dismantling the statue.

As Ruchi Chaturvedi (2015) - a UCT-based sociologist and one of the contributors to this volume - notes the RMF movement posed a comprehensive challenge to 'the hurtful milieu they live and study in - replete not just with colonial era statues and symbols but also with pedagogical and conversational modes that regard black students as deficient, necessarily

Srila wishes to acknowledge the support of the National Research Foundation of South Africa whose generous Knowledge, Interchange and Collaboration (KIC) grant made a workshop at Wits possible, the direct outcome of which is this special issue.

Srila Roy

Srila.Roy@wits.ac.za

Alf Gunvald Nilsen

alfgunvald@gmail.com

1 Department of Sociology, University of the Witwatersrand, Johannesburg, South Africa

2 Department of Sociology, University of Bergen, Bergen, Norway

3 The Society, Work and Development Institute, University of the Witwatersrand, Johannesburg, South Africa 
lagging in the civilizational race, and with course content that tells their history and describes their African present as above all a site of failure and lack.' This became particularly evident as the fall of the Rhodes statue - celebrated by the RMF movement as 'symbolic for the inevitable fall of white supremacy and privilege at our campus' (http://rhodesmustfall.co.za/) - sparked similar movements in other universities across South Africa, which pursued an agenda centred on demands for the decolonization of universities and university education in the country. Indeed, amongst the core demands of the initial RMF movement was the implementation of ' $\mathrm{a}$ curriculum which critically centres Africa and the subaltern. By this we mean treating African discourses as the point of departure - through addressing not only content, but languages and methodologies of education and learning - and only examining Western traditions in so far as they are relevant to our own experience' (https://www.facebook.com/RhodesMustFall/posts/ 1559394444336048). In addition, the RMF movement also called for radical changes in the representation of black lecturers across faculties and university decision-making bodies.

Interestingly, the call for the decolonization of the university that rose from the South African student movement in 2015 is echoed in and paralleled by campaigns by Black and Minority Ethnic (BME) students in the former colonial metropolis. For example, at the University College of London, the initiative WhyIsMyCurriculum SoWhite? called attention to the fact that 'BME students find themselves unrepresented, their histories and cultures completely ignored in the academic field because for many years white writing and history has been given a higher standing, and universities continue to perpetuate this idea of certain sources holding academic privilege.' (Hussain 2015). Similarly, Oxford University witnessed the upshot of its own RhodesMustFall movement. Like its South African namesake, its aims include ridding the university campus of colonial iconography, but it also extends much beyond this by insisting that it is necessary to reform 'the Euro-centric curriculum to remedy the highly selective narrative of traditional academia - which frames the West as sole producers of universal knowledge - by integrating subjugated and local epistemologies. This will create a more intellectually rigorous, complete academy' (https://rmfoxford.wordpress.com/about/).

Ultimately, what the project of decolonizing the university that is being articulated by student movements across the North-South axis of the world system revolves around is a challenge, as anthropologist Suren Pillay (2015) noted in a speech given at Azania House during the student occupation, to epistemic violence:

[Epistemic violence] authorizes thinking about Others in ways that enables political and economic violence to be enacted on the bodies of subject men and especially women. It also authorizes ignorance since it reinforces the prejudice that there is nothing much to learn from these parts of the world that could make us better, or help us create a better world. That is what we are talking about when we say we have a Eurocentric worldview in our education. It centers the idea of Europe, as a metaphor, and turns all others into bit players or loiterers without intent on the stage of world history, either too lazy to do anything ourselves or always late, and running behind to catch up with Western modernity.

The flipside to such epistemic violence is the epistemic justice that Robbie Shilliam speaks of in this issue as 'a reckoning with the racialized inequalities of knowledge cultivation that have historically accompanied the European colonial project'. It is thus no surprise that Shilliam also turns to current protests by black students in the North as struggles for epistemic justice. As Pillay points out, undoing epistemic violence and achieving epistemic justice is a task that is fraught with difficulties and that can be approached in many ways. He argues: 'The question might then be asked of you and us, do you want to return us to the particular against 
the universal, do you want us to step out of the global and the cosmopolitan and only think about the local, is relevance as a criteria for knowledge not the straight jacket of parochialism and narrow thinking?' To this, he suggests an alternative - namely 'that the way to think about decolonization and the universal is not to concede the universal to an imperial imagination, but to work towards a truly universal universalism. We need not give up then on the uni in the university, but we can try to redefine the very idea of the university itself.'

The reason why we start this introduction with an account of recent student movements is that the projects of decolonizing the university which they have articulated - their questions, their claims, their demands, and their visions - resonate with pivotal critiques of the discipline of sociology that have been gaining momentum in recent years. Writing as early as 1982, Wolf (1982: 5) noted that in the Western social sciences, we have become accustomed to thinking that 'there exists an entity called the West, and that one can think of this West as a society and civilization independent of and in opposition to other societies and civilizations.' This line of thought, he argued, is linked to the underlying assumption within the social sciences that societies and civilizations can be understood as 'internally homogenous and externally distinctive and bounded objects' (Wolf 1982: 6). About the discipline of sociology, he added that it had become particularly wedded to the idea that 'social relations take place within the charmed circle of the single nation-state ... Each society is then a thing, moving in response to an inner clockwork' (Wolf 1982: 9).

This 'methodological nationalism' (Chernilo 2011) is arguably wedded to a conceptual deep structure that is defined by Eurocentrism. This, indeed, is the argument that is at the heart of Bhambra's (2007) seminal indictment of historical sociology, where she points out that modernity tends to be understood as a social formation that emerged from a temporal rupture with a traditional past and that this rupture was unique to the West. Hence, the emergence of, for example, industrial capitalism and the modern nation-state-institutional hallmarks of modernity - comes to be understood as strictly Western achievements. The non-Western world is sequestered off in a realm of traditional otherness and only later drawn into the ambit of modernity. One of the logical corollaries of this conceptual narrative, Bhambra argues, is the erasure of the crucial role played by colonialism in the making of the modern world.

Connell (2007) has pursued a different line of critique in her work on sociological theory. Dominant paradigms of sociological theory, she maintains, are characterized by a distinct 'westernness' - witness only the near total dominance of Western scholars in our theoretical canons - that is concealed beneath a thin veneer of claims to universality. These claims to universality are problematic: in a fascinating reading of Coleman, Giddens, and Bourdieu, Connell shows how sociological theories that make claims to universal validity and relevance consistently evade colonialism as a historical process and experience when analyses of social relations, societal institutions, and structural change are articulated. The same pattern characterizes sociological theories of globalization. The underlying logic remains the same: a system of theoretical categories is created in the West and then turned outwards, in the direction of the global South, where the categories are then filled with empirical data. The majority worldand lest we forget, that means the global South - is thus reduced to being merely an object for a thoroughly Eurocentric social science.

Bhambra and Connell are of course only two of the most recent and perhaps most wellknown critics of the Eurocentric parochialism of sociology as a discipline. In the Latin American context, the Peruvian sociologist Quijano (2000) has been integral in developing a critique of what he refers to as 'the coloniality of power' - that is, the persistent legacies of European colonialism in both social orders and forms of knowledge (see also Mignolo 2012). 
Within Indian sociology, Sujata Patel has played a crucial role in criticizing both Eurocentrism and methodological nationalism and calling for a practice centred on an appreciation of the diversity of sociological traditions. 'The challenge today', she (2012: 8) writes, 'is in creating a political language and the intellectual infrastructure that can interface the many Souths, dissolve the markers of distinction between and within them and make their various voices recognize the matrix of power that has organised these divisions.' Writing from South Africa, Sitas (2014) argues that sociology's ideal types - especially those extrapolated from the European experience of modernity-have largely failed African attempts to engage with actually existing trajectories of social change. For sociology to be relevant in the African context, he argues, it will be necessary to forge 'a new epistemological, conceptual and empirical terrain' (Sitas 2014: 467) that posits the modern as a product of planetary interconnections rather than the historical offspring of a European immaculate conception.

Sitas' argument for a fundamental rethinking of the historical constitution of modernity in many ways echoes Bhambra's (2007) call for positioning the idea of 'connected histories' at the centre of our attempts to overcome the Eurocentrism of sociology. Other scholars have suggested other routes towards a more global sociology: for example, Connell (2007) seeks to construct a canon of non-Western sociological theory whereas Julian Go (2013: 28) has argued for the necessity of an ontological shift - that is, a shift from a substantialist ontology that understands the social world in terms of discrete and bounded entities to a relational ontology that emphasizes 'the interactional constitution of social units, processes, and practices'. In many ways, these can be seen as different ways of addressing the challenge articulated in Suren Pillay's speech - namely to transcend the imperial imaginary through which universals have tended to be construed in sociological thought and to move towards a genuinely universal universalism. Bhambra's (2014) recent call for 'connected sociologies' has added further momentum to the project of creating a conceptual imaginary for what she refers to as 'an always-already global age'.

At the core of this special issue is an ambition to contribute to these ongoing debates. The central question that we have come to ask ourselves is the following: how do we globalize sociology? Our responses to this question come not in the form of conceptual templates but rather as a series of engagements with different social phenomena that enable us to reflect on what genuinely globalized sociological engagement would look like. So, unlike related interventions, we approach global sociology not as a theoretical fact but as a practice - as a doing that involves particular citational, methodological, and obviously epistemological choices. Hence, many of the articles in this contribution varyingly draw on the intellectual resources of Subaltern Studies, postcolonial theory, and decolonial perspectives to pursue the project of expanding our understandings of sociology itself, as discipline, practice, and way of life. The key sites of engagement are place, politics, pedagogy, and practice - each of which is interrogated with a view towards undergirding substantial analytical advances in a discipline that for too long has been locked into what Patel (2014: 609) has rightly referred to as 'the provincialism of European universalisms'.

Part of the programme of globalizing sociology — or, as Ronaldo Munck in this volume puts it, pursuing 'sociology across the globe'-is the attention to place and relatedly, to scale. By this, we mean not merely a decentring of the West from our political imagination and epistemological orientation - an all too common call in the academy today - but attention to the scalar and spatial politics of knowledge production. Munck in his contribution to this special issue argues, for instance, that 'flat' epistemologies are inadequate to the task of understanding the highly uneven effects of globalization today. His is a plea for an alternative 
paradigm for a global sociology, drawing on a political economy perspective, which is sensitive to the uneven geographies of place and scale. Munck thus argues that global sociology could emerge through a critical Southern lens and draw-as he does in his article - on the conceptual tools of cultural political economy. A sensitivity to place understood in both a geographical and a social sense - namely that of class - is a key to this perspective. We could go further to say that Munck's arguments provide the foundation for a place-sensitive rather than a place-based global sociology. Munck argues that a genuinely global sociology must be based on an understanding of the socially constructed nature of space and scalar hierarchies if we are to displace the idea of the West and/or the North as the default scale of both analysis and politics.

An attention to the politics of place and scale is also central in a number of the other contributions to this volume. Robbie Shilliam, for instance, underscores the legacies and contributions of pan-African pedagogies not only for those in the South (from where they originate) but for the struggles of those who he refers to as 'the South in the North' or postcolonial populations settled in the North (as in the UK, his point of departure). Focusing on the noted Pan-Africanist politician and educator Edward Blyden, Shilliam explores how Blyden's aims and methods of liberal education - even though they were products of the South - might come to inform struggles for epistemic justice by black peoples in the contemporary UK context - a context, he notes, that is marked by the onslaught of neoliberalization in higher education. His answer to this question-particularly in the conclusion to his rich article - offers many resources to the student movements we started this introduction with and some of whom are his direct addressees. The recovery of such traditions of liberal education not only speaks to the concerns of epistemic justice and even violence that are central to Pillay's argument above but also to the neoliberalizing imperatives of universities today, whether in the North or the South. In the final instance, Shilliam recovers the history of a pan-African pedagogy not only just in the name of epistemic justice for black people located in the metropole or in the post-colony but also for a greater range of actors-black people in black-dominated locales - and structures beyond the university. Ultimately, he provides us with a sociological pedagogy that is historically aware and rooted, contemporaneous, globally attentive in terms of place and scale, and concerned with the epistemic aspects of ongoing struggles for justice.

The connection between epistemology and politics is another key focus of our combined attempt to globalize sociology. At least three of the articles are explicitly interested in exploring the political from the vantage point of and on behalf of a critical global sociology, each with its own particular thematic focus. Alf Nilsen's is development-the Eurocentric politics and practice of which there have been many substantial critiques. While he is sympathetic to these 'post-development' criticisms of the discourse of development, Nilsen charts an alternative line of critique that emphasizes the multiple meanings of the idiom of development and locates the source of this multiplicity in conflicting political projects that aim to shape the form and direction of social change in different ways. In so doing, he displaces the 'West and the Rest' binary that still shapes much development critique and argues that development works simultaneously as a tool of power and of resistance. Nilsen draws on his ethnography of the Narmada Bachao Andolan in India - especially the fractured nature of the politics of opposing the Narmada Valley dam projects - to illustrate what he calls the 'multivalence' of the idiom of development. His contribution has much to offer critical and activist scholars in and of the Global South who are currently engaged with how social movements take shape around antiglobalization, post-development and decolonial discourses, and agendas. It also carries lessons 
for the project of globalizing sociology - especially in the importance it lays on deconstructing ideal types that underlie our academic and activist investments in pure narratives of power and resistance. Nilsen paints instead a picture of a more complex world that complicates the prospect of resistance to power and calls for scholarly practices that are sensitive to the intricacies of social movements on the ground.

In her contribution, Srila Roy takes as her point of departure the Indian women's movement. In so doing, she provides substance to Munck's provocation that 'a new global sociology will need to engage with the rich debate around the politics of scale in geography if it is to be successful in its mission'. The article underscores the politics and ethics of scale in reading women's movements in the Global South. Roy demonstrates that attempts to globalize feminism have historically served only to reinforce Western hegemony and to silence the Third World feminisms. The epistemic violence is obvious: even as recent processes of transnationalization and NGOization of women's movements represent significant moments of scale-shifting, 'feminism' continues to be associated with that which is 'Western'. Nevertheless, Roy argues, women's movements in the global South have asserted a stridently transnational orientation that defies the hegemony of Western feminism in global histories of women's struggles for liberation, and this poses conceptual challenges for sociological engagement with Southern feminisms. The article uses the anti-rape protests that erupted in India in 2012 over the gang rape and murder of a young student in Delhi as a way of thinking through the changing scales and sites of contemporary feminist protest in the global South. A reading of these protests calls for new spatial concepts and scalar epistemologies to emphasize their multi-scalar dimensions, internally non-homogenous nature and polyvalent meaning of 'feminism' itself. So, while Nilsen speaks of fault lines within social movements as raising serious ethnographic, epistemological, and ethical challenges for those writing these movements, Roy's point is, similarly, that a uni-scalar analysis would not be able capture or adequately represent the complexity of the deep cleavages in the anti-rape movement in contemporary India. The multivalence of social movements that they both emphasize also bring about unexpected possibilities of critique, struggle, and solidarity that have to equally be the object of 'sociology across the globe' as Munck puts it.

The final contribution on the political comes from Ruchi Chaturvedi who takes as her point of departure the role of the urban poor or the so-called informal or lumpenproletariat in popular protests in West Africa. As a key to a project of globalizing sociology, Chaturvedi describes these critical agents of resistance in their specific contexts and describes the nature of political imaginations, possibilities, and agency that they have enacted. She writes: 'These contexts and narratives alert us to various political possibilities and violent limits of popular politics. At the same time they lay the grounds for grasping another mode of imagining, enacting and understanding protest.' In order to explore the possibilities and limits of popular protests more broadly, she focuses on the Nigerian artist Jelili Atiku and his political performance towards the end of the Occupy Nigeria movement in January 2012. Seen in the light of writings on the lumpenproletariat, the 'thirdwave' of protests, and new research on politics of the informal working class in Africa, his performance opens up novel interpretive threads including the manner in which the local becomes the pre-eminent scale of political intervention besides other spatial arrangements around 'political society' (Chatterjee 2004) — a now dominant trope of reading popular protest in the South. Chaturvedi also notes the internal differences or fault lines within the 'urban underclass' that are occluded in many discussions on urban protest, once again arguing for a more developed paradigm for reading resistance. Jelili Atiku's street 
performance could also be read through Shilliam's conception of epistemic justice especially when it comes to popular protest in that it affirms 'that the knowledge systems of such communities (including their fault-lines) are resources that, in principle, hold epistemic authority when it comes to identifying what counts as a problem, what constitutes the problem and what are the means of redress'.

We end this special issue with a clear instance of the actual practice of globalizing sociology — of linking pedagogy, politics, and practice - in a reflection on a collaborative arts and research project between European and South African cultural organizations. In illustrating the complexities of such a North-South collaboration as well as between higher education and non-academic partners, Alison Rooke's article considers these to be an opportunity-however modest - to develop a genuinely public sociology. Rooke understands public sociology in Burawoy's sense as being 'concerned with how to work reflexively with diverse publics in dialogue to produce sociological knowledge'. The collaborative project that is her case study is an instance of such a global sociology in involving and engaging debate 'amongst multi-level, translocal sociological publics'. Rooke focuses on the considerable tensions and unequal power relations between partners as intrinsic to the nature of such collaborations: it is impossible to wish away such power relations or to consider them through the idiom of failure; rather, they have to be interrogated in a productive manner. She is also sceptical of the potential of what she calls a professional sociology to produce genuinely public sociology in the context of internationalization of higher education and the drive for 'world class' universities (in ways that resonate with Shilliam's broader critique of neoliberal university culture and practice in the North). At the same time, she notes a more potentially positive fallout of the globalization of higher education institutions in the North especially in terms of its shifting scales of - from the North to the South - as challenging Eurocentrism in sociological knowledge production and practice.

Thus, we end as we began this issue — with a focus on the university or rather, of the role of the university in decolonizing knowledge and enabling forms of epistemic in/justice (and also in South Africa, which is also a part of Rooke's case study). Rooke's is an important reminder of the concrete methodological challenges of globalizing sociology in higher education institutions today, when, all said and done, theory and funding rarely 'travel' in the same direction - that is, from the South to the North. The politics of place, pedagogy, and practice renew commitments to critique and dismantle the hegemony of Northern theory even as they make more apparent theory's travelling nature. We hope the essays in this issue offer some concrete insights and direction for a programme of globalizing sociology through their combined commitment to decolonization and social justice and in their attention to critical pedagogies of space and place and possibilities for solidarity building as well as internal contest. We hope that together they should be capable of generating important debates well beyond the disciplinary boundaries of sociology while, at the same time, taking an important step in the direction of undermining sociology's Eurocentric deep structure. In Conversations with Bourdieu: The Johannesburg Moment, Burawoy (2012: 211) contends that 'to transcend the dominance of the North is a Sisyphean task, so we must avoid illusory solutions, the substitution of dream for reality'. This is indeed a sobering reminder of the difficulties of globalizing sociology in an already globalized world. We hope these articles, read individually or together, will offer concrete resources to those involved in this difficult project, which involves nothing less than decolonizing and democratizing spaces and structures of higher learning today — whether in South Africa, India, Chile, or the UK and 
US - and re-establishing the role of the university in constituting a public culture and space of dissent.

Open Access This article is distributed under the terms of the Creative Commons Attribution 4.0 International License (http://creativecommons.org/licenses/by/4.0/), which permits unrestricted use, distribution, and reproduction in any medium, provided you give appropriate credit to the original author(s) and the source, provide a link to the Creative Commons license, and indicate if changes were made.

\section{References}

Bhambra, G. (2007). Rethinking modernity: postcolonialism and the sociological imagination. London: Palgrave.

Bhambra, G. (2014). Connected sociologies. London: Bloomsbury.

Burawoy, M. (2012). Travelling theory. In M. Burawoy \& K. Von Holdt (Eds.), Conversations with Bourdieu: The Johannesburg moment (pp. 210-218). Johannesburg: Wits University Press.

Chatterjee, P. (2004). Politics of the governed: reflections on popular politics in most of the world. New York: Columbia University Press.

Chaturvedi, R. (2015). The rise of a postcolonial university. Article available on http://africasacountry.com/2015/ 04/the-rise-of-a-post-colonial-university/

Chernilo, D. (2011). The critique of methodological nationalism. Theory and history. Thesis Eleven, 106(1), 98-117.

Connell, R. (2007). Southern theory: the global dynamics of knowledge in social science. London: Allen and Unwin.

Go, J. (2013). For a postcolonial sociology. Theory and Society, 42(1), 25-55.

Hussain, M. (2015). Why is my curriculum so white? Article available on http://www.nus.org.uk/en/news/whyis-my-curriculum-white

Mignolo, W. (2012). Local histories/global designs: coloniality, subaltern knowledges, and border thinking. Princeton: Princeton University Press.

Patel, S. (2012). Towards internationalism: beyond colonial and nationalist sociologies. Article available at http:// www.isa-sociology.org/publ/E-symposium/E-symposium-vol-2-3-2012/EBul-Patel-Dec2012.pdf

Patel, S. (2014). Afterword: doing global sociology: issues, problems and challenges. Current Sociology, 62(4), 603-613.

Pillay, S. (2015). Decolonizing the university. Article available on http://africasacountry.com/2015/06/ decolonizing-the-university/

Quijano, A. (2000). Coloniality of power and eurocentrism in Latin America. International Sociology, 15(2), $215-232$.

Sebambo, K. (2015). Azania house as a symbol of the black imagination. Article available on http://www.jwtc. org.za/the_salon/volume_9/khumo_sebambo.htm

Sitas, A. (2014). Rethinking Africa's sociological project. Current Sociology, 62(4), 457-471.

Wolf, E. (1982). Europe and the people without history. Berkeley: University of California Press. 